\title{
Improving the Mechanical Properties of Lightweight Foamed Concrete Using Silica Fume and Steel Fibers
}

\author{
Suhad M. Abd \\ Dhamyaa Ghalib \\ Civil Eng. Dep., Diyala University, Diyala, IRAQ \\ dhamya.ghalib@gmail.com \\ Received: 26-Dec.-2017 \\ Revised: 17-Jan.-2017 Accepted: 12-March-2018 \\ http://doi.org/10.29194/NJES21020300
}

\begin{abstract}
Lightweight foamed concrete (LWFC) is characterized as a light in self-weight, selfcompacting, self-levelling, and thermal and sound isolation. But it has low strength and low ductility which leads that the application of (LWFC) in the building construction is limited. The flowability of the fresh mix of (LWFC) was evaluated by flow test. While the hardened properties of (LWFC) include, compressive strength, tensile splitting strength, flexural strength, and modulus of elasticity. This study focuses on the effect of the adding of silica fume and steel fibre on the mechanical properties of (LWFC). Silica fume was added as $(5 \%)$ and $(10 \%)$ by the weight of cement and steel fiber $(0.2 \%)$ and $(0.4 \%)$ of the total volume of the mix. The density of lightweight foamed concrete was $1800 \pm 50 \mathrm{~kg} / \mathrm{m}^{3}$, and cement to sand ratio was (1:1) with water cement ratio $(0.28)$. The results indicated that adding of silica fume and steel fiber have great effect on the mechanical properties and improve them. The addition (10\%) of silica fume and $(0.4 \%)$ by volume of steel fiber was the best ratio that improves the mechanical properties of the lightweight foamed concrete (LWFC). The pozzolanic index of the $(5 \%)$ and $(10 \%)$ silica fume was (21.9\%) and (74.76\%), respectively.
\end{abstract}

Keywords: lightweight, foamed concrete, mechanical properties, steel fiber, silica fume.

\section{Introduction:}

Lightweight foamed concrete, is a type, of concrete has a lighter, weight compared with normal concrete. Using lightweight foamed concrete as a construction material lead to reduce the self-weight of a structure and offers better thermal and sound insulation and better fire protection than normal weight concrete. Foamed or cellular concrete was defined by (ACI523.3R-1993) as "The cellular concretes referred to in this guide are lightweight concrete that contain stable air or gas cells uniformly distributed in the mixture. In the density range covered by this guide, cellular concretes commonly include natural or manufactured sand aggregate.” [1]

According to the ACI 116R-00, silica fume is defined as " a very fine non-crystalline silica produce in electric arc furnaces as a by-product of the production of elemental silicon or alloys containing silicon” [2]. In 1923, Axel Eriksson got the first patented of Portland cement based foamed concrete. Over the past 20 years, the development of production tools, foaming agent, and superplasticizers have contributed to the use of lightweight foamed concrete on a wide scale, and much researchers have been made to investigate the properties and applications of (LWFC) and the possibility of the using (LWFC) in structural applications [3]. In comparing the mechanical properties, lightweight concrete is certainly no corresponded with normal concrete especially in its compressive strength. But many researchers are trying to enhance the performance of lightweight foamed concrete through enhancing its mechanical properties and durability by including fibres.

In (2010) Suhad M. studied the effect of different additives and fibres on the mechanical properties of lightweight foamed concrete for different densities in the range of (1200-1800 $\mathrm{kg} / \mathrm{m}^{3}$ ) with silica fume (5-15\%), and steel fiber was used in the range of $(0.25-0.5 \%)$. From the results steel fiber significantly increased the compressive strength of (LWFC) for all ranges of density at all ages as compared to the mixes without fibers [4]. In (2012) Awang and Ahmad studied the steel fiber effect as $(0.25 \%$ and $0.4 \%)$ by total volume fraction on the mechanical properties and durability of lightweight foamed concrete with density $1000 \mathrm{~kg} / \mathrm{m}^{3}$. They found that steel fiber improve the mechanical properties of lightweight foamed concrete due to the LWFC is characterized by a porous structure inside, so the presence of steel fiber acts as the reinforcement that supports this structure [5].

In (2015) Mydin and Sahiduna studied the mechanical properties; compressive strength, flexural strength and tensile splitting strength, of lightweight foamed concrete contain steel fiber with volume fraction $(0.2 \%$ and $0.4 \%)$ and found that the adding the steel fibres improve the mechanical properties of LWFC [6].

The lightweight foamed concrete (LWFC) is characterized by a very brittle material with a low compressive strength and low splitting tensile strength. In (2015) Hilal et al. studied the adding of silica fume to enhance the properties of foamed concrete. They found that adding silica fume improved the 28 days compressive strength of 
foamed concrete by about $10 \%$ due to use of a superplasticizer and the pozzolanic characteristics of silica fume [7].

This research aims to study the mechanical properties of lightweight foamed concrete with the addition of silica fume and steel fiber in terms of compressive, flexural, splitting tensile strengths, and modulus of elasticity.

\section{Experimental Work \\ 2.1 Material \\ 2.1.1 Cement}

Ordinary Portland cement used in this study to produce lightweight foamed concrete. It conform to the Iraqi Standard Specification (I.Q.S. No.5, 1984) [8]. Table 1. and Table 2. show the chemical and physical properties of cement used in this study, respectively.

\subsection{Silica Sand}

Fine aggregate used was imported fine standard sand with a specific gravity of 2.60 and percentage from size 600 micro no 3. (Al-Umaraa) company supplies this type of sand. Table 3 shows the sieve analysis of sand used in this study according to ASTM C778 [9].

Table (1): Chemical properties of cement

\begin{tabular}{|c|c|c|}
\hline $\begin{array}{c}\text { Oxide } \\
\text { composition }\end{array}$ & $\begin{array}{c}\text { Results \% } \\
\text { by weight }\end{array}$ & $\begin{array}{c}\text { Limit of Iraqi } \\
\text { specification } \\
\text { No.5/1984 }\end{array}$ \\
\hline $\mathrm{SiO}_{2}$ & 20.4 & - \\
\hline $\mathrm{CaO}$ & 61.7 & - \\
\hline $\mathrm{Al}_{2} \mathrm{O}_{3}$ & 5.45 & - \\
\hline $\mathrm{Fe}_{2} \mathrm{O}_{3}$ & 4.79 & - \\
\hline $\mathrm{MgO} \mathrm{SO}_{3}$ & 1.5 & 5.0 (max) \\
\hline $\mathrm{C}_{3} \mathrm{~A}$ & 1.9 & 2.8 (max) \\
\hline $\mathrm{C}_{3} \mathrm{~S}$ & 47.23 & - \\
\hline $\mathrm{C}_{2} \mathrm{~S}$ & 23.06 & - \\
\hline $\mathrm{C}_{4} \mathrm{AF}$ & 14.6 & - \\
\hline $\begin{array}{c}\text { Insoluble } \\
\text { Residual (I.R) }\end{array}$ & 0.42 & 1.5 (max) \\
\hline $\begin{array}{c}\text { Loss of } \\
\text { Ignition (L.O.I) }\end{array}$ & 2.08 & 4.0 (max) \\
\hline
\end{tabular}

Table (2): Physical properties of cement

\begin{tabular}{|c|c|c|}
\hline $\begin{array}{c}\text { Physical properties } \\
\text { test }\end{array}$ & Results & $\begin{array}{c}\text { Limit of Iraqi } \\
\text { specification No. } \\
5 / 1984\end{array}$ \\
\hline $\begin{array}{c}\text { Fineness using } \\
\text { Blaine air } \\
\text { permeability } \\
\text { apparatus }\left(m^{2} / \mathrm{kg}\right)\end{array}$ & 405 & 230 (min) \\
\hline $\begin{array}{c}\text { Soundness using } \\
\text { autoclave method }\end{array}$ & - & $0.8 \%$ (max) \\
\hline
\end{tabular}

\begin{tabular}{|c|c|c|}
\hline $\begin{array}{c}\text { Setting time using } \\
\text { Vicat’s instruments }\end{array}$ & 135 & $00: 45$ (min) \\
Initial(min.) & $3: 25$ & $10: 00$ (max) \\
Final(hr.) & & 15 (min) \\
\hline $\begin{array}{c}\text { 3-day compressive } \\
\text { strength for cement } \\
\text { Paste }\end{array}$ & $24.2 \mathrm{MPa}$ & 23 (min) \\
\hline $\begin{array}{c}\text { 7-day compressive } \\
\text { strength for cement } \\
\text { Paste }\end{array}$ & $32.5 \mathrm{MPa}$ & \\
\hline
\end{tabular}

Table (3): The sieve analysis of silica sand

\begin{tabular}{|c|c|c|}
\hline Sieve size & Passing\% & $\begin{array}{c}\text { Limit of ASTM } \\
\text { C778 }\end{array}$ \\
\hline $1.18 \mathrm{~mm}$ & 100 & 100 \\
\hline $600 \mu \mathrm{m}$ & 94.5 & $96-100$ \\
\hline $300 \mu \mathrm{m}$ & 22.6 & $20-30$ \\
\hline $150 \mu \mathrm{m}$ & 4.65 & $0-4$ \\
\hline pan & 0.0 & 0 \\
\hline
\end{tabular}

\subsubsection{Superplasticizers}

Is an additive based on modified polystearicesters free of chlorides, whose action is improves concrete flow without segregation. The superplasticizer "Sika Viscocrete 5930" was used which complies with (ASTM C494/C494M, 2015) types $\mathrm{G}$ and $\mathrm{F}$ [10]. Table 4 . shows the properties of superplasticizers.

Table (4): Properties of Superplasticizers

\begin{tabular}{|l|l|}
\hline Form / Color & Liquid, amber \\
\hline Density (at $\left.25^{\circ} \mathrm{C}\right)$ & Approximately $1.11 \mathrm{~kg} / \mathrm{lt}$ \\
\hline Specific Gravity & $1,07 \pm 0,01 \mathrm{~kg} / \mathrm{L}$ \\
\hline $\mathrm{pH}$ & Approximately 5.5 \\
\hline Chloride Content & Nil (EN 934-2) \\
\hline
\end{tabular}

\subsubsection{Silica fume}

Silica fume is an additive for concrete and mortars. It meets the requirements of (ASTM C1240) [11] and (ASTM C-618) [20]. Table 5 shows the properties of silica fume.

Table (5): Silica fume properties.

\begin{tabular}{|c|c|c|c|}
\hline Form/Color: & $\begin{array}{c}\text { Grey } \\
\text { Powder }\end{array}$ & $\begin{array}{c}\text { Limit of } \\
\text { ASTM } \\
\text { C1240 }\end{array}$ & $\begin{array}{c}\text { Limit of } \\
\text { ASTM } \\
\text { C618 }\end{array}$ \\
\hline Surface area & $27.3 \mathrm{~m}^{2} / \mathrm{g}$ & $\begin{array}{c}\text { Min } \\
15 \mathrm{~m}^{2} / \mathrm{g}\end{array}$ & ----- \\
\hline Bulk density & $660 \mathrm{~kg} / \mathrm{m} 3$ & ------ & ----- \\
\hline Moisture content & $0.6 \%$ & Max 3\% & Max 3\% \\
\hline Loss on ignition & $3.4 \%$ & Max 6\% & Max 6\% \\
\hline Sulfuric anhydride & $0.3 \%$ & ------ & ---- \\
\hline $\begin{array}{c}\text { Total Silica } \\
\text { Content SiO2 }\end{array}$ & $94.7 \%$ & Min 85\% & Min 70\% \\
\hline Available alkali & $0.01 \%$ & ------- & Max 0.05\% \\
\hline Chloride ion & $0.055 \%$ & ------ & ----- \\
\hline Relative strength & $116 \%$ & Min 105\% & ------ \\
\hline
\end{tabular}




\subsubsection{Water}

Tap water will be used, and which shall be clean and free organic materials.

\subsubsection{Foaming Agent}

Foam is a form of stable bubbles, produced by mixing foaming agent and water in foam generator. The purpose of the foam is to control the density of lightweight foamed concrete by incorporating dry preformed stable foam into fresh lightweight foamed concrete. For this study the ratio of foaming agent to water was $(1: 30)$ by volume. Table 6 shows the properties of foaming agent. It is produce lightweight foamed concrete according to ASTM C796/C796M [12].

Table (6): Properties of foam agent.

\begin{tabular}{|c|c|}
\hline Appearance / Colour & Yellow transparent liquid \\
\hline Chemical Base & $\begin{array}{c}\text { Air entraining synthetic } \\
\text { liquid }\end{array}$ \\
\hline Density & $\begin{array}{c}1.0075-1.0175 \mathrm{~kg} / \mathrm{L} \text {, at } \\
20^{\circ} \mathrm{C}\end{array}$ \\
\hline $\mathrm{pH}$ Value & $9-11$ \\
\hline $\begin{array}{c}\text { Total Chloride Ion } \\
\text { Content }\end{array}$ & Max. $0.1 \%$, Chloride-free \\
\hline
\end{tabular}

\subsubsection{Steel Fiber}

In this study, the steel fiber used are hooked-end low carbon produces by Sika with length $(60 \mathrm{~mm})$, aspect ratio $(\mathrm{L} / \mathrm{d}=80)$. It was tested according to (ASTM A820) [13]. Fig. 1 shows the geometry of steel fiber used.

Table (7): Mix proportion.

\begin{tabular}{|c|c|c|c|c|c|c|}
\hline Mix & $\begin{array}{l}\text { Cement } \\
\left(\mathrm{kg} / \mathrm{m}^{3}\right)\end{array}$ & Sand & $\begin{array}{c}\text { Water } \\
\left(\mathrm{kg} / \mathrm{m}^{3}\right)\end{array}$ & Sp & $\begin{array}{c}\text { Silica } \\
\text { fume\% }\end{array}$ & $\begin{array}{c}\text { Steel } \\
\text { fiber\% }\end{array}$ \\
\hline FB & 787.23 & 787.23 & 275.5 & 0 & 0 & 0 \\
\hline F SP5 & 811.4 & 811.4 & 227.2 & 0.5 & 0 & 0 \\
\hline F $\quad$ SP8 & 811.4 & 811.4 & 227.2 & 0.8 & 0 & 0 \\
\hline F SF 5 & 789.25 & 789.25 & 232 & 0.8 & 5 & 0 \\
\hline $\begin{array}{ll}\mathrm{F} & \text { SF } 10 \\
\end{array}$ & 768.3 & 768.3 & 236.6 & 0.8 & 10 & 0 \\
\hline F $\quad$ ST1 & 761.8 & 761.8 & 234.6 & 0.8 & 10 & 0.2 \\
\hline $\begin{array}{ll}\text { F } & \text { ST2 }\end{array}$ & 755.3 & 755.3 & 232.6 & 0.8 & 10 & 0.4 \\
\hline
\end{tabular}

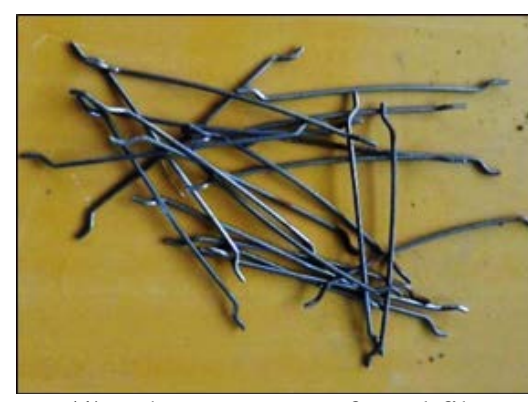

Figure (1): The geometry of steel fibres.

\subsection{Preparing Foaming Agent:}

To prepare foaming agent the liquid of foam and water are added to the foam pump generator by ratio (foam: water) is (1:30), and with pressure to get the foaming agent output as shown in Fig.2.

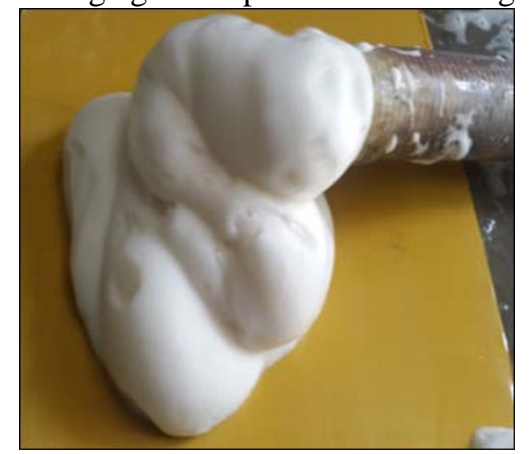

Figure (2): Foam output

\subsection{Producing Lightweight Foamed Concrete}

The foam is prepared first by adding foaming agent with water to the foam generator, the foam is produced with presence of air. The objective of this research is improving the properties of control mix lightweight foamed concrete by using the addition of two types of fibers which are steel fiber. Portland cement and silica fume of (10\%) by the weight of cement were used as the cementitious materials. the water/cementitious materials ratio was 0.28 , and superplasticizers of $(0.5 \%$ and $0.8 \%)$ by the weight of cementitious materials. The base mix is prepared by mix the dry material; cement, sand, and silica fume in the mixer with the cement-sand ratio of
(1:1). After the dry materials are mixed well, water premixed with superplasticizers is added to the base mix. Table 7 shows the material and mix design. When the mortar become ready, the steel fiber is added. After that foam agent is added to the mix and the mortar density was measured. Promptly after mixing, the concrete was placed in molds in order to prevent breaking down of the air bubbles before it was set. At about 24 hours after that, concrete molds were removed and warped with nylon to prevent moisture evaporation.

\subsection{Curing}

The foamed concrete samples is cured by nylon warped and kept it in the medium temperature. 


\section{Experimental Tests}

\subsection{Fresh Properties Test (Flow Test)}

This test of concrete mix is done to give us some idea on the workability of concrete mix as shown in Fig.3 according to the standard specification ASTM C1437 [14]. The flow result can be calculated as in the eq.(1):

$$
\text { Flow }=\frac{d_{1}-d_{2}}{d_{2}} \times 100
$$

Where $d_{1}$ is the average of four readings in (mm), $d_{2}$ is the original inside base diameter in $(\mathrm{mm})$.

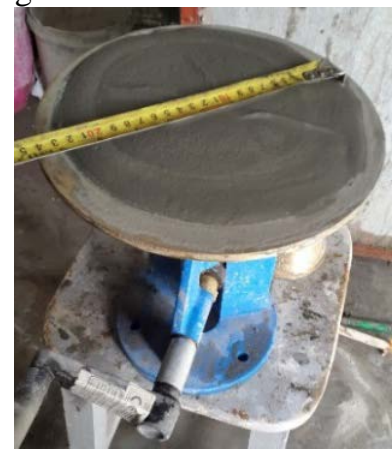

Figure (3): Flow test

\subsection{Hardened Properties Tests 3.2.1Compression Test}

The compressive strength of LWFC is a significant property because it indirectly provides the other mechanical properties such as flexural strength, tensile splitting strength, and elasticity modulus. Compression test is required to determine the concrete strength as in Fig.4 according to BS1811-116 is used cubes moulds with diminution $(100 * 100 * 100 \mathrm{~mm})$ [15].

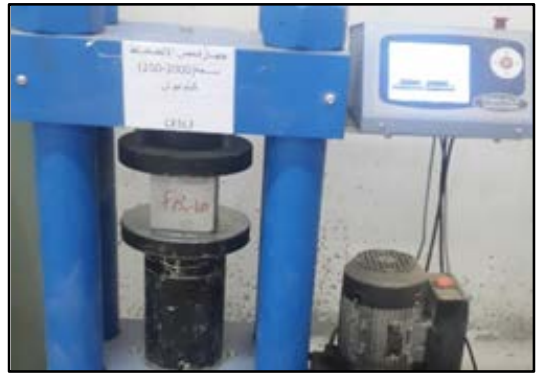

Figure (4): Compression test.

\subsubsection{Tensile Splitting Test}

Tensile splitting test of concrete is the method to measures the tensile splitting strength of concrete of given mixes proportion by the application of a diametric compression load on a cylindrical concrete specimen with diameter $(150 \mathrm{~mm})$ and height $(300 \mathrm{~mm})$ placed with its axis horizontal between the plates of a testing machine according to ASTM C496 [16] as seen in Fig.5. Splitting tensile strength can calculated using eq.(2):

$$
f_{t}=\frac{2 P}{\pi L d}
$$

Where $f_{t}$ : is the tensile splitting strength of concrete specimen in (MPa),

$\mathrm{P}$ : applied load in $(\mathrm{N})$,

$\mathrm{L}$ : is the cylinder length in ( $\mathrm{mm})$, and

$\mathrm{d}$ : is the cylinder diameter in (mm).

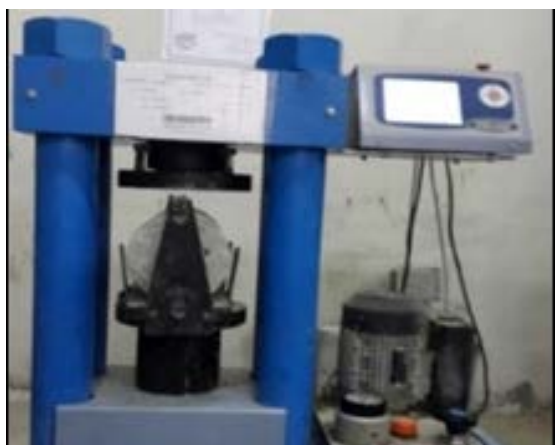

Figure (5): Splitting tensile test.

\subsubsection{Flexural Test}

The objective of this testing is to determine the modulus of rupture of lightweight foamed concrete using prism dimension $(100 * 100 * 500 \mathrm{~mm})$ according to ASTM C78/C78M [16], as seen in Fig.6. The modulus of rupture can be calculated by the eq. (3):

$$
f_{r}=\frac{P L}{b d^{2}}
$$

where $f_{r}$ : is the modulus of rupture in (MPa),

$\mathrm{P}=$ applied $(\mathrm{N})$,

$\mathrm{L}=$ the prism length in $(\mathrm{mm})$,

$\mathrm{b}=$ the prism width in (mm),

$\mathrm{d}=$ the prism depth, $\mathrm{mm}$

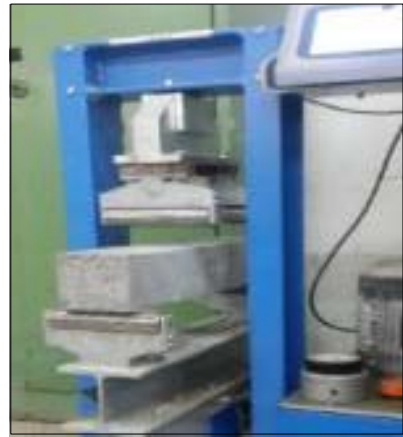

Figure (6): Flexural test.

\subsubsection{Modules of elasticity}

The modulus of elasticity of an object is defined as the slope of its stress-strain curve obtain from the test as shown in Fig.7. This test is produced according to ASTM C469/C469M [18]. The modulus of elasticity can be calculated by the eq.(4):

$$
\mathrm{E}_{\mathrm{c}}=\frac{S_{2}-S_{1}}{\varepsilon_{2}-0.000050}
$$


Where $E_{c}$ is chord modulus of elasticity in (GPa), $S_{2}$ is the stress identical to $40 \%$ of ultimate load, $S_{1}$ is the stress identical to a longitudinal strain $\left(\varepsilon_{1}\right)$ of (0.000050), and $\varepsilon_{2}$ is longitudinal strain produced by stress $S_{2}$.

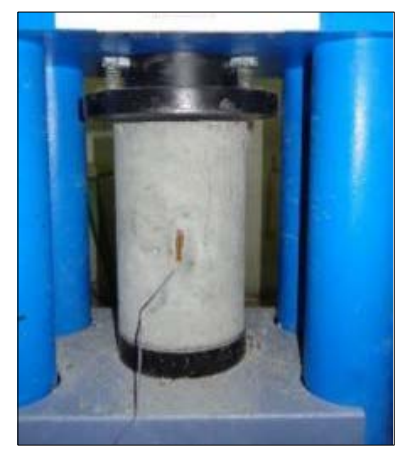

Figure (7): Modulus of elasticity test.

\section{Results and Discussion}

\subsection{Flow test}

Lightweight foamed concrete is characterized by having a high workability because it is consist of fine particles in addition to high w/c ratio or superplasticizer. The adding of superplasticizer in the LWFC increase the workability and flowability of the mix. The adding of silica fume reduce the flow slightly. Due to its large surface area which absorbed the water of mixing. The adding of the steel fiber into the mix of LWFC reduces the flowability of the mix as the result Fig. 8 which include the result of the flow test for all mixes.

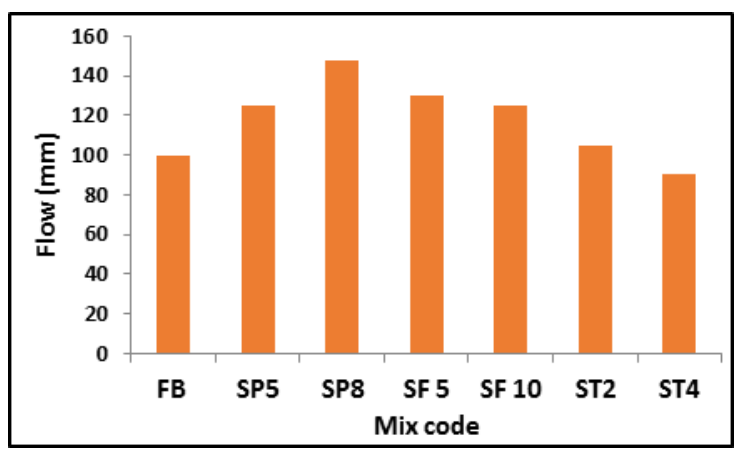

Figure (8): Flow test result of all mixes.

\subsection{Compressive strength}

Lightweight foamed concrete has a low compressive strength comparing with normal concrete. The reducing of water to cement ratio of the mix by using superplasticizer leads to improve the compressive strength for the same mix. As shown in Fig. 9 the adding silica fume into the (LWFC) improves the compressive strength of lightweight foamed concrete significantly due to the pozzolanic characteristics of silica fume leading to an improved the matrix bond of concrete [7]. According to standard (ASTM C1240-14) the pozzolanic index of the (5\%) silica fume was (21.9\%) and for (10\%) silica fume was (74.76\%).
Also the adding steel fiber improves the compressive strength of lightweight foamed concrete due the steel fiber matrix bond mechanism and amount percentage of steel fiber introduce into the lightweight foamed concrete [6].

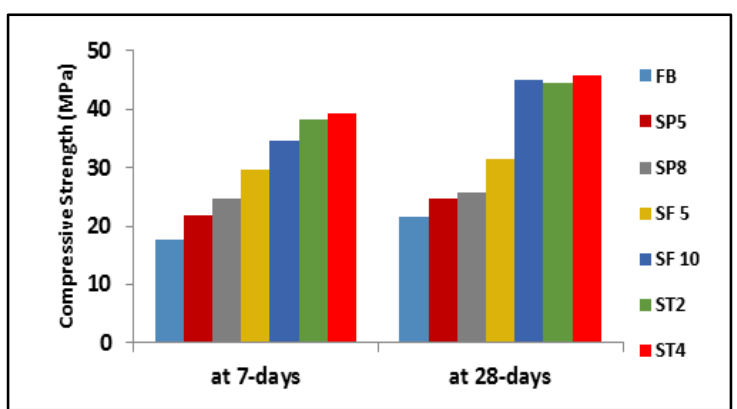

Figure (9): Compressive strength test results.

\subsection{Tensile Splitting strength}

Tensile splitting strength is generally higher than direct tensile strength and less than flexural strength (modulus of rupture). Tensile strength is used in the design of structural lightweight concrete members to evaluate the shear resistance provided by concrete and to determine the development length of reinforcement ASTM C496/C496M [16]. From the test results shown in Fig.10, the adding silica fume enhance the tensile splitting strength on LWFC mix due to the pozzolanic action of silica fume which can provide the strength of foamed concrete mix, so that it can resist more applied loads before failure. The adding steel fiber increases the tensile splitting strength of lightweight foamed concrete because the hook-end shape of the steel fiber are sufficiently strong and bonded to lightweight foamed concrete mix.

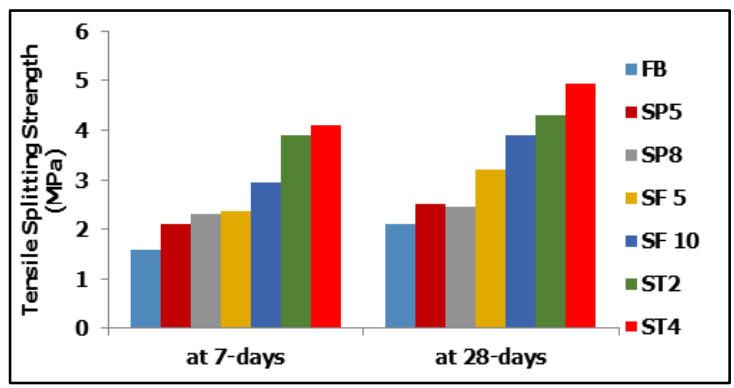

Figure (10): Tensile splitting strength test results.

In (2010) Suhad [4] used the non-linear regression to developing a model to predict the tensile splitting strength of lightweight foamed concrete as in equation (5):

$$
f_{t}=0.1096\left(f_{c}\right)^{0.8268}
$$

Where $f_{t}$ : Tensile splitting strength of lightweight foamed concrete in MPa;

$f_{c}{ }^{\prime}$ : Cylinder compressive strength of lightweight foamed concrete in 28 days in MPa.

From Table 8. and Fig.11 which show the tensile splitting strength results, there is no match between the results obtained from the experimental test and 
the results calculated based on the power equation (5). But the equation (5) improve that the tensile splitting strength of light weight foamed concrete mixes increases with the increasing of the compressive strength.

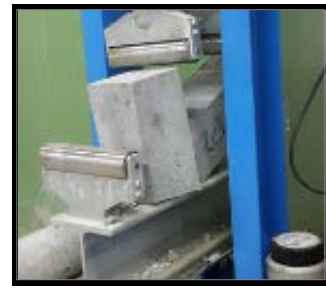

(a) Complete failure of control specimen without the inclusion of fiber

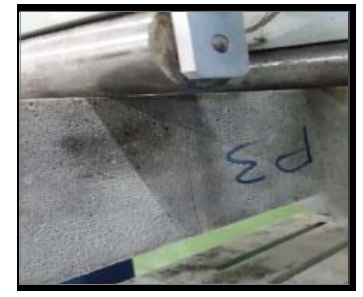

(b) flexure failure of specimen with fiber inclusion

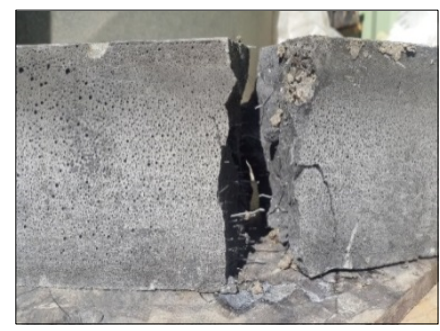

(c) Cross section of samples with fibre after test

Figure (13): Flexural strength test specimen.

Table (8): Tensile Splitting Strength test results

\begin{tabular}{|c|c|c|c|c|c|}
\hline \multirow[b]{2}{*}{ Mix } & \multirow{2}{*}{$\begin{array}{l}\text { Compressiv } \\
\text { e strength } \\
f_{c}^{\prime}(\mathrm{MPa})\end{array}$} & \multicolumn{2}{|c|}{$\begin{array}{l}\text { Tensile splitting } \\
\text { strength } f_{t}(\mathrm{MPa})\end{array}$} & \multirow{2}{*}{ 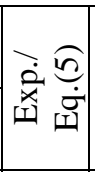 } & \multirow{2}{*}{ 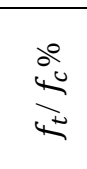 } \\
\hline & & $\begin{array}{l}\text { Exp. } \\
\text { results }\end{array}$ & Eq. (5) & & \\
\hline FB & 21.7 & 2.1 & 1.4 & 1.5 & 9.68 \\
\hline SP5 & 24.74 & 2.5 & 1.5 & 1.6 & 10.10 \\
\hline SP8 & 25.74 & 2.45 & 1.60 & 1.52 & 9.52 \\
\hline SF 5 & 31.4 & 3.2 & 1.9 & 1.68 & 10.19 \\
\hline SF 10 & 44.96 & 3.9 & 2.5 & 1.53 & 8.67 \\
\hline ST1 & 44.6 & 4.3 & 2.53 & \begin{tabular}{|l|}
1.69 \\
\end{tabular} & 9.64 \\
\hline ST2 & 45.7 & 4.93 & 2.58 & 1.90 & 10.78 \\
\hline
\end{tabular}

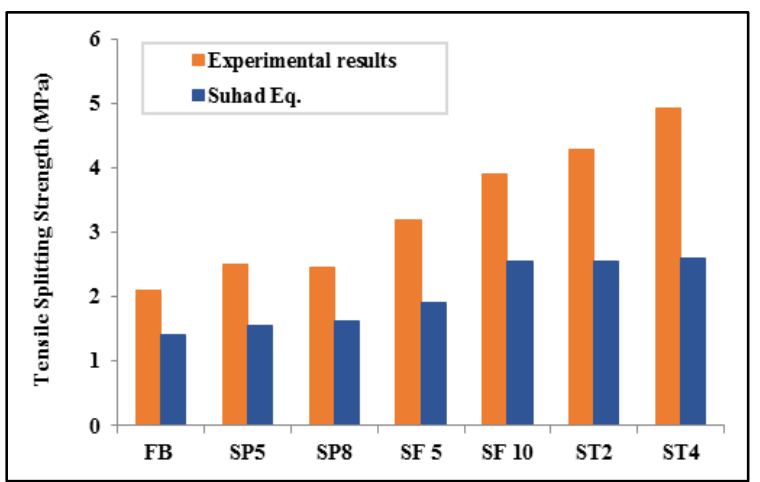

Figure (11): Compared the experimental tensile splitting strength with power equation (5).

\subsection{Flexural strength}

The most important factors that affected on the flexural strength are water to cement (w/c) ratio and compressive strength, so the using of superplasticizers and silica fume enhance the flexural strength of lightweight foamed concrete. The addition of steel fiber increasing the flexural strength as shown in Fig.12 which shows the flexural strength of lightweight foamed concrete at 7 and 28 days.

The flexural cracks on the prism were not visible until the maximum load was reached, due to continuous and bonding of fibers in the mix. This is because of steel fiber into the lightweight foamed concrete linked the cracked parts together and prevent it broken into two parts as seen in Fig. 13.

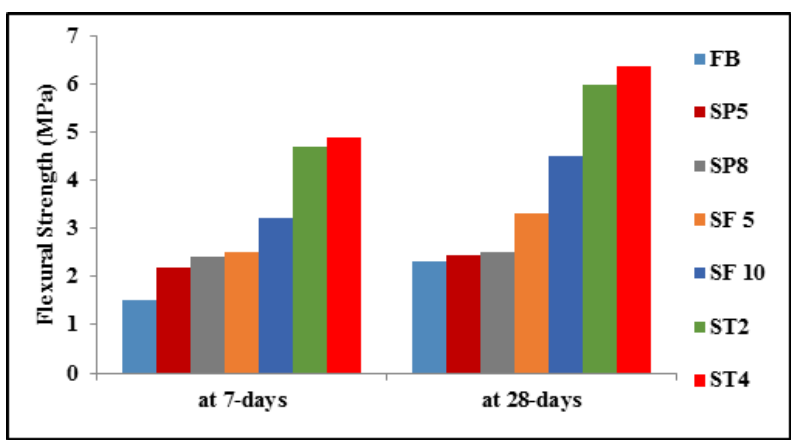

Figure (12): Flexural strength test results.

In (2010) Suhad [4] used the non-linear regression to developing a model to predict the flexural strength of lightweight foamed concrete as in equation (6):

$$
f_{r}=0.0702\left(f_{c}\right)^{1.1554}
$$

Where $f_{r}$ : is the flexural strength of lightweight foamed concrete;

$f_{c}$ : is the compressive strength of lightweight foamed concrete in 28 days.

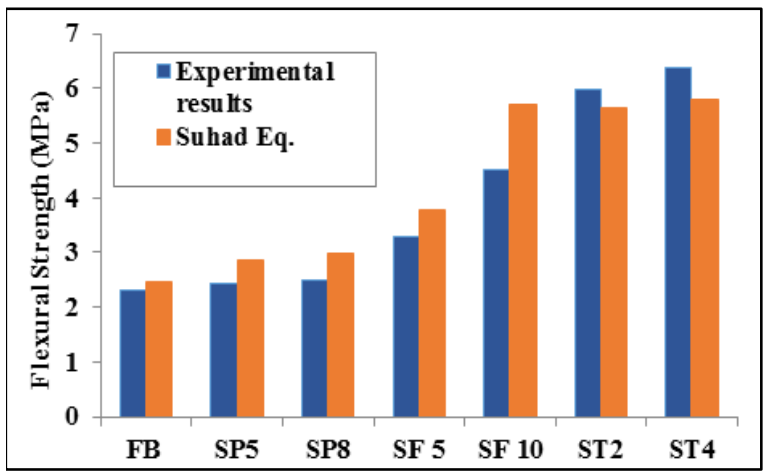

Figure (14): Compared the experimental flexural strength with power equation (6).

Table (9): Flexural strength test results.

\begin{tabular}{|c|c|c|c|c|c|}
\hline \multirow[b]{2}{*}{ Mix } & \multirow{2}{*}{ 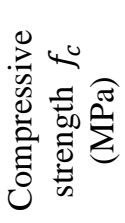 } & \multicolumn{2}{|c|}{$\begin{array}{c}\text { Flexural strength } \\
f_{r} \mathrm{MPa} \\
\end{array}$} & \multirow{2}{*}{ 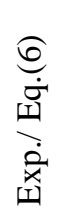 } & \multirow{2}{*}{$\frac{\partial^{0}}{4}$} \\
\hline & & $\begin{array}{l}\text { Exp. } \\
\text { results }\end{array}$ & Eq. (6) & & \\
\hline FB & 21.7 & 2.3 & 2.4 & 0.9 & 10.6 \\
\hline
\end{tabular}




\begin{tabular}{|c|c|c|c|c|c|}
\hline FSP5 & 24.74 & 2.43 & 2.8 & 0.85 & 9.8 \\
\hline FSP8 & 25.74 & 2.5 & 2.9 & 0.83 & 9.7 \\
\hline FSF5 & 31.4 & 3.3 & 3.7 & 0.88 & 10.5 \\
\hline FSF10 & 44.96 & 4.5 & 5.7 & 0.8 & 10.0 \\
\hline FST1 & 44.6 & 5.97 & 5.6 & 1.05 & 13.4 \\
\hline FST2 & 45.7 & 6.37 & 5.81 & 1.1 & 13.9 \\
\hline
\end{tabular}

From Table 9 and Fig.14 which show the flexural strength results, there is a high convergence between the results obtained from the experimental test and the results calculated based on the power equation (6).

\subsection{Modulus of elasticity}

The modulus of elasticity is calculated as the secant modulus from the slope of the experimental stress-strain curve for cylinder compressive test at the point where the material changed from liner to non-liner behavior as the slope of the line drawn from zero stress to a compressive stress of $\left(0.45 f_{c}{ }^{\prime}\right)$. The modulus of elasticity of lightweight foamed concrete depends on the compressive strength of concrete. From test results shown in the figure 15 , the adding of silica fume to the foamed concrete increases the modulus of elasticity. this because the adding of silica fume increases the stress capacity of the mix.

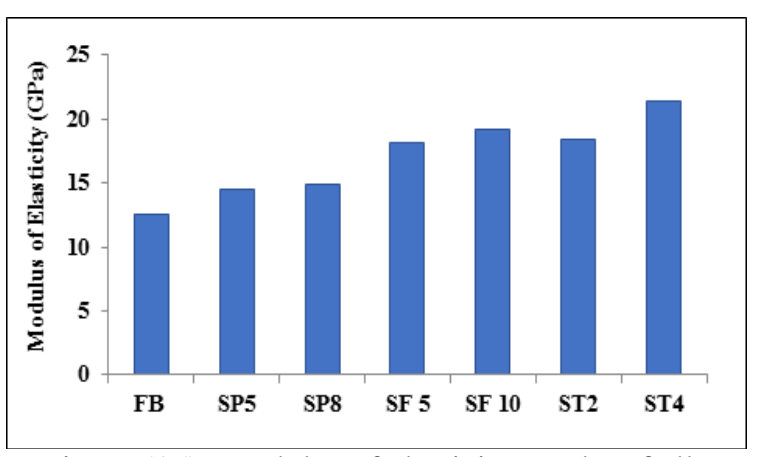

Figure (15): Modulus of elasticity results of all mixes.

According to ACI318-14 [19] the elastic modulus of lightweight concrete can be calculated depending on the unit weight (density) and the compressive strength of lightweight concrete at 28 days as the equation (7) :

$$
\mathrm{E}_{\mathrm{c}}=w_{c}{ }^{1.5} 0.043 \sqrt{f_{c}{ }^{\prime}}
$$

Where $E_{c}$ : modulus of elasticity of lightweight concrete in $\mathrm{GPa}$,

$w_{c}$ : unit weight of lightweight concrete between $\left(1440-2560 \mathrm{~kg} / \mathrm{m}^{3}\right)$,

$f_{c}{ }^{\prime}$ : compressive strength of concrete at 28 days.

As seen in Figure (16) and Table (10), there is a high convergence between the experimental test results which obtain from the slope of stress-strain curve and the result obtain by the ACI-318-14 equation [19].

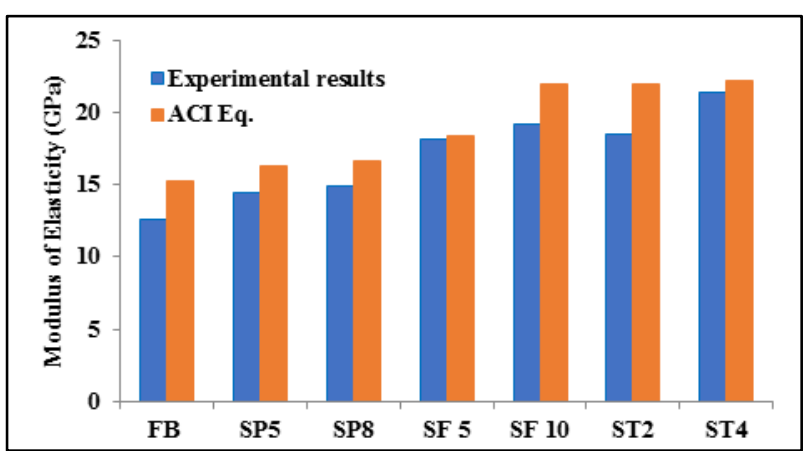

Figure (16): Compared the experimental modulus of elasticity with ACI Eq. (7).

Table (10): Modulus of Elasticity Test Results

\begin{tabular}{|c|c|c|c|c|}
\hline \multirow[t]{2}{*}{ Mix } & \multirow{2}{*}{ 总. } & \multicolumn{2}{|c|}{$\begin{array}{l}\text { Modulus of } \\
\text { elasticity } E_{c} \\
\times 10^{-3}(\mathrm{GPa})\end{array}$} & \multirow{2}{*}{ 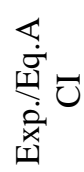 } \\
\hline & & Exp. & Eq. ACI & \\
\hline FB & 21.7 & 12.6 & 15.3 & 0.82 \\
\hline FSP5 & 24.74 & 14.5 & 16.3 & 0.88 \\
\hline FSP8 & 25.74 & 14.9 & 16.66 & 0.89 \\
\hline FSF 5 & 31.4 & 18.1 & 18.4 & 0.98 \\
\hline FSF10 & 44.96 & 19.2 & 22.01 & 0.87 \\
\hline FST1 & 44.6 & 18.5 & 21.93 & 0.89 \\
\hline FST2 & 45.7 & 21.4 & 22.19 & 0.96 \\
\hline
\end{tabular}

\section{Conclusions:}

The behavior of the adding of silica fume (5\% and $10 \%$ ), and the adding of steel fiber at volume fraction $(0.2 \%$ and $0.4 \%)$ on the mechanical properties of lightweight foamed concrete were investigated. The following conclusions are drawn from this study:

1. The adding silica fume to the LWFC mix improve the compressive strength. The pozzolanic index of the (5\%) silica fume was (21.9\%) and for (10\%) silica fume was (74.76\%).

2. In compared with control mix (FB), the adding of the silica fume as (5\%) and (10\%) increases the compressive strength as (22\%,59\%), flexural strength as (32\%, 80\%), tensile splitting strength as (30.6\%, 55\%), and modulus of elasticity as $(21.5 \%, 29 \%)$, respectively.

3. In compared with mix without fibers (SF10), the adding of steel fiber as $(0.2 \%)$ and $(0.4 \%)$ into the LWFC mix increases the compressive strength as (9\%) and (11.6\%), the flexural strength as (32\%) and $(41.6 \%)$, the tensile splitting strength as (34.4\%) and (26.4\%), and modulus of elasticity as (8.5\%) and (11.45\%), respectively.

4. By the comparison between the results from the experimental test of this study and the results predicted according (Suhad M., 2010), the flexural strength shows a high convergence and the tensile strength shows a low convergence.

5. For modulus of elasticity, there is a high convergence between the experimental test results which obtain from the slope of stress-strain curve and the result obtain by the ACI-318-14 equation. 


\section{Rreferences}

[1] ACI Committee 523.3R. (1993). Guide for Precast Cellular Concrete Floor, Roof, and Wall Units. American Concrete Institute.

[2] ACI Committee 116R, (2000). Cement and Concrete Terminology. American Concrete Institute.

[3] Amran Y.H., Farzadnia N., Ali A.A., (2015). Properties and applications of foamed concrete; a review. Construction and Building Materials, 101 990-1005.

[4] Abd, S. M., (2010). Potential of light weight foamed concrete as sustainable structure material by optimization and utilzation of waste materials. Doctoral dissertation. University Kebangsaan Malaysia.

[5] Awang, H. and Ahmad, M. H. (2012). "The effect of steel fiber inclusion on the mechanical properties and durability of lightweight foam concrete”, Elixir Adv. Egg. Info. Vol.48 , pp. 93489351.

[6] Mydin, M. A., Sahiduna, N. S., Yusof, M. Y., Noordina, N. M. (2015). "Compressive, Flexural and Splitting Tensile Strength of Lightweight Foamed Concrete with Inclusion of Steel Fibers", Journal Technology, vol.75:5, pp.45-50.

[7] Hilal, A. A., Thom, N. H., \& Dawson, A. R. (2015). The use of additives to enhance properties of pre-formed foamed concrete. International Journal of Engineering and Technology, 7(4), 286.

[8] Iraqi Specifications No. (5). (1984). Portland cement. Baghdad-Iraq. Iraqi Central Organization for Standardization and Quality Control.

[9] ASTM C778. (2013).Standard Specification for Standard Sand. Philadelphia, PA: American Society for Testing and Material.

[10] ASTM C494/C494M. (2015). “Standard Specification for Chemical Admixtures for Concrete". American Society for Testing and Material International, Philadelphia, PA, USA.

[11] ASTM C1240. (2015). "Standard Specification for Silica Fume Used in Cementitious
Mixtures”. American Society for Testing and Material International, Philadelphia, PA, USA.

[12] ASTM C796/C796M. (2012). "Standard Test Method for Foaming Agents for Use in Producing Cellular Concrete Using Preformed Foam”. American Society for Testing and Material International, Philadelphia, PA, USA.

[13] ASTM A820. (2011). "Standard Specification for Steel Fibers for Fiber-Reinforced Concrete” American Society for Testing and Material International, Philadelphia, PA, USA.

[14] ASTM C1437. (2013). "Standard Test Method for Flow of Hydraulic Cement Mortar" American Society for Testing and Material International, Philadelphia, PA, USA.

[15] British Standard Institute. Testing concrete Method for determination of compressive strength of concrete cubes. BS1811-116.

[16] ASTM C496. (2011). "Standard Test Method for Splitting Tensile Strength of Cylindrical Concrete Specimens”. American Society for Testing and Material International, Philadelphia, PA, USA.

[17] ASTM C78. (2015). "Standard Test Method for Flexural Strength of Concrete (Using Simple Beam with Third-Point Loading)”. American Society for Testing and Material International, Philadelphia, PA, USA.

[18] ASTM C469/C469M. (2014). "Standard Test Method for Static Modulus of Elasticity and Poisson's Ratio of Concrete in compression" American Society for Testing and Material International, Philadelphia, PA, USA.

[19] ACI Committee 318, (2014). American Concrete Institute, and International Organization for Standardization. Building code requirements for structural concrete (ACI 318-14) and commentary. American Concrete Institute.

[20] ASTM C618 (2012) Standard Specification for Coal Fly Ash and Raw or Calcined Natural Pozzolan for Use in Concrete. American Society for Testing and Materials

\section{تحسين الخواص الميكانيكية للخرسانة الرغوية الخفيفة الوزن باستخدام دخان السيليكا والالياف الفولاذية}

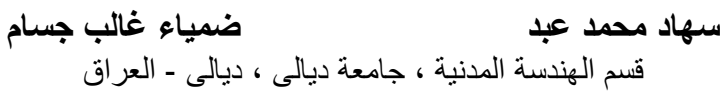

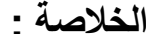

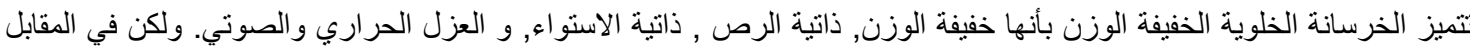

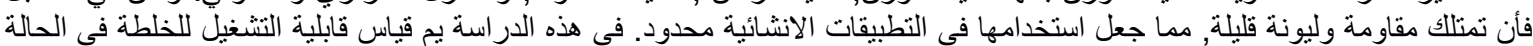

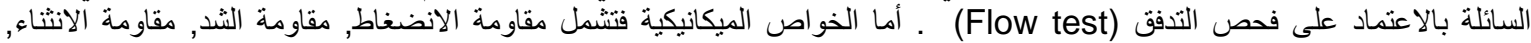

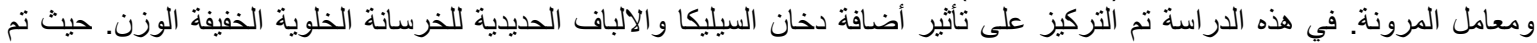

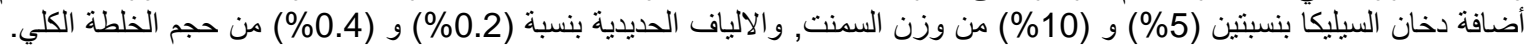

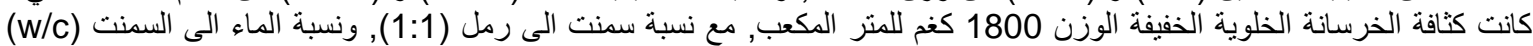

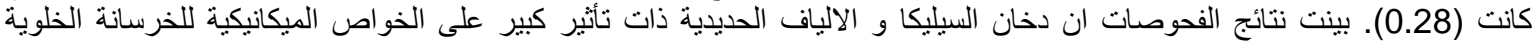

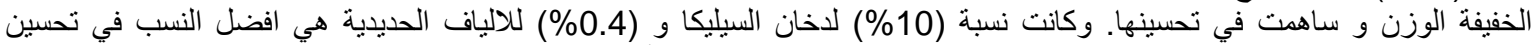

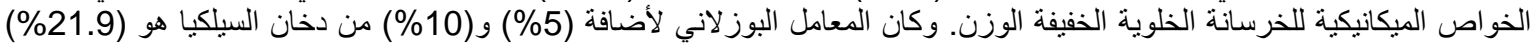
و (74.76\%) ، على التو الي. 